\title{
ELISA inhibition technique for the demonstration of sulphones in body fluids
}

\author{
II. A new method to monitor leprosy \\ patient compliance under field conditions* \\ H HUIKESHOVEN, MADELEINE de WIT, \\ ANYA SOETERS, J E LANDHEER \& D L LEIKER \\ Royal Tropical Institute, Amsterdam, The Netherlands
}

Received for publication 30 September 1980

\begin{abstract}
Summary An enzyme-linked immunosorbent assay (ELISA) for sulphones in urine is described. This method for monitoring dapsone (DDS) selfadministration is compared with the quantitative determination of DDS/ creatinine $(\mathrm{D} / \mathrm{C})$ ratios, currently used. Urine samples collected from 10 volunteers on 14 consecutive days after taking single doses of $100 \mathrm{mg}$ DDS are studied, together with pretreatment samples and urine containing standard amounts of DDS. The lowest quantity of DDS still visually detectable by ELISA inhibition is $0.01 \mu \mathrm{g} / \mathrm{ml}$ urine. All samples obtained up to 4-10 days after the $100 \mathrm{mg}$ DDS doses are positive by this method, whereas the first negative $\mathrm{D} / \mathrm{C}$ results occur on the third day. The method is especially apt to monitor substantial failure in DDS self-administration without using sophisticated instruments.
\end{abstract}

\section{Introduction}

A current method to monitor the self-administration of dapsone (DDS) by leprosy patients is based on colorimetric estimation of the DDS/creatinine (D/C) ratio in urine. The method discriminates between blank control urine samples and urine samples of patients on DDS doses as low as $25 \mathrm{mg}$ per day. Also urine samples collected within 2 or 3 days of a single $200 \mathrm{mg}$ DDS dose were classified positive by this technique. The method was especially advocated by Ellard and colleagues ${ }^{1}$ for quantitative estimation of percentages of selfadministered doses that are actually being taken by groups of out-patients. With this aim it has been applied successfully to leprosy patients in Africa and Asia. ${ }^{2-13}$

${ }^{*}$ This investigation received support from the Chemotherapy of Leprosy (THELEP) component of the UNDP/World Bank/WHO Special Programme for Research and Training in Tropical Diseases, from the Netherlands Leprosy Relief Association (Nederlandse Stichting voor Leprabestrijding) and from the Italian Leprosy Relief Association (Amici dei Lebbrosi). 
However, the method has several limitations:

(1) Variations in $\mathrm{D} / \mathrm{C}$ ratios between controls on the same supervised DDS dose are too large for conclusions to be drawn as to the number of missed doses of DDS that might have preceded an individual low $\mathrm{D} / \mathrm{C}$ ratio. ${ }^{1}$

(2) The estimation of low $\mathrm{D} / \mathrm{C}$ ratios is limited by other diazotizable substances causing apparent $\mathrm{D} / \mathrm{C}$ values in blank control urines. These values vary within a population, and also between different populations. ${ }^{1,2,4}$

(3) Compliance estimation may be hindered by the presence in urine of sulphonamides that cross-react with DDS in the colorimetric estimation. Measurement at a second wavelength is needed to avoid misleading results. ${ }^{2}$

(4) The method requires a spectrophotometer, a costly and vulnerable instrument, not readily available in rural leprosy endemic areas.

In view of these limitations it is understandable that the WHO Expert Committee on Leprosy in its fifth report ${ }^{14}$ asks for simpler methods for analysing urine for dapsone content. The increasing incidence of resistance of Mycobacterium leprae to DDS makes a convenient method for checking leprosy patient compliance urgently needed in order to distinguish between relapse due to non-compliance and that due to the emergence of sulphore-resistant $M$. leprae. Such a method is also of importance in attempts to improve DDS selfadministration, since poor compliance is probably a factor promoting the emergence of sulphone resistance.

We have therefore developed an enzyme-linked immunosorbent assay (ELISA) for DDS in urine. It is an inhibition technique essentially corresponding to an idea of Engvall and Perlmann, ${ }^{15}$ first applied by Holmgren and Svennerholm in $1973^{16}$ for the detection of Vibrio cholerae antigen in sera. Preliminary experiments with urine samples from 44 Kenyan leprosy patients have shown the high sensitivity of the basic technique, using whole rabbit antiDDS serum and enzyme conjugated anti-rabbit IgG serum. ${ }^{17}$ The main tool for the test in its present form is the sulphones specific antibody-enzyme conjugate described in our previous paper. ${ }^{18}$ This paper describes the method for detecting sulphones in urine, and compares its qualities with those of the $\mathrm{D} / \mathrm{C}$ method.

\section{Materials and methods}

\section{URINE SAMPLES}

Each of 10 healthy volunteers took a single oral dose of $100 \mathrm{mg}$ DDS. Urine samples were collected immediately before the DDS doses were taken and on 14 consecutive days thereafter, from each volunteer one $10 \mathrm{ml}$ sample per day. Early morning urine was avoided. Half of each sample was preserved by the 
addition of a few grains of thymol. To each of the other $5 \mathrm{ml}$ portions $2.5 \mathrm{ml}$ $2 \mathrm{~N} \mathrm{HCl}$ was added.

\section{REAGENTS FOR ELISA}

The following reagents were prepared according to the prescriptions laid down in the previous paper: ${ }^{18}$ Bovine Serum Albumin-DDS conjugate (BSA-DDS), lyophilized in carbonate buffer of $\mathrm{pH} 9.6$ in vials containing $20 \mu \mathrm{g}$ BSA-DDS each, stored at room temperature; sulphones specific enzyme-immunoglobulin conjugate (the E-Ig dialyzate of the previous paper), mixed in portions of $125 \mu \mathrm{l}$ dialyzate with $500 \mu$ l normal horse serum and $50 \mu$ l Tween 20 , lyophilized and stored at $+4{ }^{\circ} \mathrm{C}$; purified 5 -aminosalicylic acid (5 AS), lyophilized and stored at room temperature in portions of $10 \mathrm{mg}$ per vial.

Other reagents used were thymol, Tween 20, 5\% aqueous phenol red solution, diluted ammonia solution, $\mathrm{HCl}, \mathrm{NaOH}, \mathrm{H}_{2} \mathrm{O}_{2}$, and phosphate buffered saline (PBS), containing $1.72 \mathrm{~g} \mathrm{Na}_{2} \mathrm{HPO}_{4} .12 \mathrm{H}_{2} \mathrm{O}, 0.254 \mathrm{~g} \mathrm{KH}_{2} \mathrm{PO}_{4}$ and $8.5 \mathrm{~g} \mathrm{NaCl}$ per 1 of water.

\section{DEMONSTRATION OF SULPHONES BY ELISA}

Before analysis each urine sample was roughly adjusted to $\mathrm{pH} 7 \mathrm{by}$ the addition of a few drops of diluted ammonia solution or diluted $\mathrm{HCl}$, using phenol red as indicator. The presence of DDS and its conjugates in urine samples was demonstrated by an ELISA inhibition technique. A vial with lyophilized buffered BSA-DDS was filled with $10 \mathrm{ml}$ tap water, dissolving the conjugate. To each of the 96 wells of a microtiter tray $100 \mu \mathrm{l}$ of this solution was added. The tray was covered (e.g. with a second one) and left to incubate for $15 \mathrm{~min}$ at $56^{\circ} \mathrm{C}$. Then the tray was emptied and washed 4 times with PBS containing $0.05 \%$ Tween 20 (PBS/Tween), each time leaving the fluid in the wells for $1 \mathrm{~min}$. Before the next incubation $25 \mu \mathrm{l}$ PBS/ Tween was added to each well, followed by $25 \mu \mathrm{l}$ of a urine sample. A vial with lyophilized E-Ig (one portion as described above) was filled with $5 \mathrm{ml}$ tap water, dissolving the conjugate. To each well of the tray $50 \mu$ l of this solution was added. The tray was again covered and left to incubate for $15 \mathrm{~min}$ at $56^{\circ} \mathrm{C}$. It was then emptied and washed 4 times with PBS/Tween as described above. Finally to each well $100 \mu \mathrm{l}$ substrate was added, prepared by dissolving a $10 \mathrm{mg}$ lyophilized $5 \mathrm{AS}$ portion in $9 \mathrm{ml}$ distilled water, and then mixing it with $1 \mathrm{ml}$ of a $0.05 \%$ solution of $\mathrm{H}_{2} \mathrm{O}_{2}$ in distilled water. After leaving the tray for $2 \mathrm{~h}$ at room temperature, the colour intensities resulting from the test samples were compared with those resulting from the pretreatment samples, and from a mixture of the latter to which standard amounts of DDS were added. Comparison was made with the naked eye. 
ESTIMATION OF D/C RATIOS B Y SPECTROPHOTOMETRY

DDS/creatinine ratios of the acidified urine specimens were estimated as described by Ellard and colleagues. ${ }^{1}$

\section{Results}

Figure 1 is a photograph of ELISA results using the urine samples from 5 of the 10 volunteers. The first 2 rows show the results after using standard amounts of DDS in urine. The lowest quantity of DDS still detectable in these standard samples by naked eye is $0.01 \mu \mathrm{g} / \mathrm{ml}$ urine, i.e. $0.25 \mathrm{ng} /$ well (wells E 1-2). Likewise, in urine specimens collected up to 8 days after the $100 \mathrm{mg}$ dose of DDS the naked eye could easily detect sulphones by ELISA. In the case of one volunteer even the urine collected on the tenth day was unmistakably positive (well C8). Similar results were obtained with the other urine samples, except in those of one volunteer, when the limit of detection was reached already on the fourth day after the DDS dose was taken. DDS/creatinine determinations proved that this particular volunteer was an extremely rapid DDS eliminator with an estimated T $\frac{1}{2}$ (half-life) for DDS of $11 \mathrm{~h}$, compared to the average $T \frac{1}{2}$ among this group of volunteers of $22 \mathrm{~h}$ (range $11-34 \mathrm{~h}$ ).

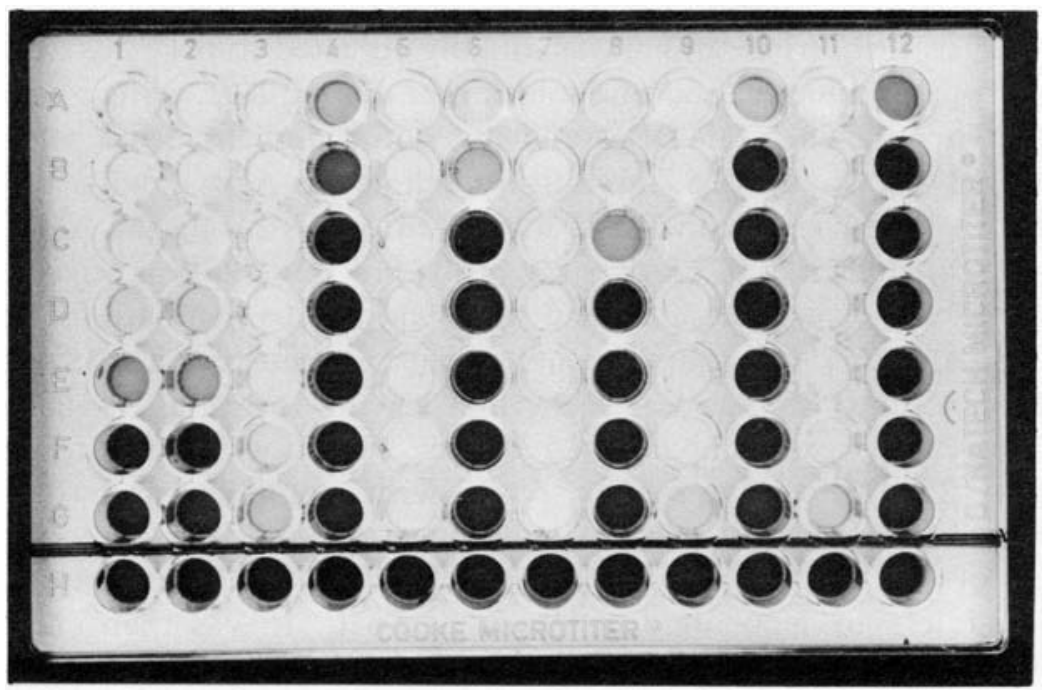

Figure 1. ELISA on urine samples to detect sulphones. Rows 1 and 2: duplicate mixed urine samples containing standard amounts of DDS, respectively 100 (A), 10 (B), 1 (C), 0.1 (D), $0.01(\mathrm{E}), 0.001(\mathrm{~F}), 0.0001(\mathrm{G})$ and $\mathrm{O}(\mathrm{H}) \mu \mathrm{g} / \mathrm{ml}$. Rows $3,5,7,9$ and 11 : urine samples from 5 different volunteers, collected respectively before treatment $(\mathrm{H})$, or on day 1 (A), 2 (B), 3 (C), 4 (D), 5 (E), 6 (F) and 7 (G) after taking $100 \mathrm{mg}$ DDS. Rows 4, 6, 8, 10 and 12: urine samples from the same 5 volunteers, collected respectively before treatment $(\mathrm{H}$, duplicate), or on day 8 (A), 9 (B), 10 (C), 11 (D), 12 (E), 13 (F) and 14 (G) after taking $100 \mathrm{mg}$ DDS. 
Table 1 compares the numbers of urine samples positive by $\mathrm{D} / \mathrm{C}$ ratios with the numbers positive by ELISA. To obtain an end-point for the positive classification by $\mathrm{D} / \mathrm{C}$ ratios either 2 or 3 standard deviations $(0.7)$ were added to the mean pretreatment value (2.8), resulting in an end-point of 4.2 and 4.9 respectively. Using an end-point of 4.2 , all samples collected up to 3 days after the $100 \mathrm{mg}$ dose of DDS are positive by $\mathrm{D} / \mathrm{C}$ ratio, but among those samples collected during the last days of the experiment some false positives are likely to have occurred. With an end-point of 4.9 , only 7 out of 10 samples are positive on the third day, but false positives are excluded. The much greater sensitivity of the ELISA is apparent from the table. When T $\frac{1}{2}$ values of DDS are normal, urines may be expected to be positive for at least a week after the taking of a single dose of $100 \mathrm{mg}$ DDS.

The ELISA results were identical, whether incubations were done for $15 \mathrm{~min}$ at $56^{\circ} \mathrm{C}$, for $30 \mathrm{~min}$ at $37^{\circ} \mathrm{C}$, or for $90 \mathrm{~min}$ at $20^{\circ} \mathrm{C}$.

Table 1. D/C and ELISA analysis of urine samples after single oral doses of $100 \mathrm{mg}$ DDS (10 subjects)

\begin{tabular}{|c|c|c|c|c|}
\hline $\begin{array}{l}\text { Time } \\
\text { (Days) }\end{array}$ & $\begin{array}{l}\mathrm{D} / \mathrm{C} \text { ratios } \\
(\mu \mathrm{g} / \mathrm{ml})^{*}\end{array}$ & $\begin{array}{c}\text { Number } \\
\mathrm{D} / \mathrm{C}>4.9^{\dagger}\end{array}$ & $\begin{array}{c}\text { Number } \\
\mathrm{D} / \mathrm{C}>4.2 \ddagger\end{array}$ & $\begin{array}{c}\text { Number } \\
\text { pos. by ELISA }\end{array}$ \\
\hline 1 & $22.5(15.2-27.8)$ & 10 & 10 & 10 \\
\hline 2 & $10.4(6.5-14.3)$ & 10 & 10 & 10 \\
\hline 3 & $6.8(4.3-10.3)$ & 7 & 10 & 10 \\
\hline 4 & $4.5(2.7-7.4)$ & 3 & 5 & 10 \\
\hline 5 & $4.1(2.5-6.4)$ & 3 & 4 & 9 \\
\hline 6 & $3.2(2.1-5.2)$ & 1 & 2 & 9 \\
\hline 7 & $3.0(1.7-4.3)$ & 0 & 1 & 9 \\
\hline 8 & $2.9(2.1-4.7)$ & 0 & 1 & 9 \\
\hline 9 & $2.7(1.5-3.8)$ & 0 & 0 & 3 \\
\hline 10 & $2.5(1.5-3.6)$ & 0 & 0 & 1 \\
\hline 11 & $2.4(0.9-3.2)$ & 0 & 0 & 0 \\
\hline 12 & $2.5(0.4-4.6)$ & 0 & 1 & 0 \\
\hline 13 & $2.7(2.0-4.4)$ & 0 & 1 & 0 \\
\hline 14 & $2.5(0.8-4.7)$ & 0 & 1 & 0 \\
\hline
\end{tabular}

* means and ranges

$\dagger$ mean of pretreatment values (2.8) plus three standard deviations (0.7)

$\ddagger$ mean of pretreatment values plus two standard deviations

\section{Discussion}

An important advantage of the ELISA compared to the $\mathrm{D} / \mathrm{C}$ method is its higher sensitivity, even though it is read by naked eye. Reliable, positive results are obtained for up to 4-10 days after giving a single dose of $100 \mathrm{mg}$ DDS, equivalent in effect to the situation at the end of a period of daily dosage with $50 \mathrm{mg}$ DDS. Thus, finding negative results from urine samples of patients who 
were meant to be self-administering such daily doses would indicate substantial failure in self-medication. This is clinically far more important than the occasional missed dose, and cannot be revealed with precision by the less sensitive $\mathrm{D} / \mathrm{C}$ method.

Another advantage of the ELISA is its relative simplicity. No sophisticated instruments are required. A single microtiter tray will suffice for duplicate samples of 36 test specimens, 6 positive and 6 blank controls. For positive controls one might either use urine specimens containing a range of known DDS concentrations, as in this study, or serial dilutions of a mixture of urine samples from a small number of patients, whose DDS administration is strictly supervised. The latter will be easier to prepare in the field. It will also allow a more adequate comparison between control and test samples since both will contain a natural mixture of conjugated and unconjugated sulphones, each with its own affinity for the E-Ig conjugate. ${ }^{18}$

The turning-point of colour change should be included in the series of dilutions of the control urine. If that is done, calculations based on a $T \frac{1}{2}$ of 1 day will give an indication of what the average negative urine result implies. It should be stressed, however, that the broad variations in diuresis and in $T \frac{1}{2}$ for DDS do not allow any conclusions to be drawn as regards individual patients in anything more than general terms such as substantial non-compliance. Even quantitative tests, that include the creatinine determination as a correction factor for the diuresis, can avoid this limitation only by the laborious way of comparing individual results with those obtained after the same patient had taken supervised doses of DDS. ${ }^{1,2}$ Those who are interested in the omission of only 2 or 3 daily DDS doses should make different dilutions of the test samples, to find out at which dilutions a positive sample turns negative. Conclusions must again be based on average $\mathrm{T} \frac{1}{2}$ values, with the unavoidable restriction that a slow eliminator remains longer positive than a rapid eliminator, all other factors being equal.

For some leprosy workers such semi-quantitative interpretations of the ELISA may appear unnecessary or too troublesome. They want a simple yes or no answer to the compliance question. In this case, it may only be necessary to include 6 positive and 6 negative control urine samples, all undiluted. Any negative test result points to substantial non-compliance without further interpretation. Strict standardization of the reagents, giving reproducible tests under changing circumstances, does permit this simplification, thus making the test more attractive for the man in the field.

Although in the laboratory it was convenient to carry out our incubations at $56^{\circ} \mathrm{C}$, clearly in the field incubations would be best done for 90 minutes at ambient temperature.

The shelf-life of two of the three lyophilized reagents is very long. They remained stable even when being kept at $56^{\circ} \mathrm{C}$ for one month. The third reagent, the specific E-Ig conjugate, remains in optimal condition kept at $4^{\circ} \mathrm{C}$ for one year, and at $37^{\circ} \mathrm{C}$ for 25 days. 
The total production costs of the three lyophilized reagents per microtiter tray are about US \$15 (E-Ig, \$13; BSA-DDS, \$1; 5AS, \$1). These figures are an indication of the present situation. Other costs are the tray $(\$ 0.50)$, the washing fluid and some chemicals ( $\$ 0.50$ per tray). The trays may be recycled by intensive washing with $1 \%$ sodium dodecyl sulphate (SDS) and water, or with $1 \mathrm{~N} \mathrm{NaOH}$ and carbonate buffer. If the investment of US $\$ 100$ for an adjustable pipette is prohibitive, simple plastic pipettes $(\$ 0.25$ each $)$, calibrated for drops of 25 or $50 \mu \mathrm{l}$ of water and operated with a small balloon may be used.

In conclusion, this ELISA inhibition technique may be of some help to workers supervising leprosy treatment in endemic areas, especially where a growing resistance of $M$. leprae to sulphones occurs.

\section{Acknowledgements}

The authors are indebted to the volunteers for taking doses of DDS and giving the materials for this study.

\section{References}

${ }^{1}$ Ellard GA, Gammon PT, Helmy HS, Rees RJW. Urine tests to monitor the selfadministration of dapsone by leprosy patients. Am J Trop Med Hyg, 1974, 23, 464-70.

${ }^{2}$ Ellard GA, Gammon PT, Harris JM. The application of urine tests to monitor the regularity of dapsone self-administration. Lepr Rev, 1974, 45, 224-34.

${ }^{3}$ Low SJM, Pearson JMH. Do leprosy patients take dapsone regularly? Lepr Rev, 1974, 45, $218-23$.

${ }^{4}$ Huikeshoven HCJ, Honhoff C, Van Eys GJJM, Anten JGF, Mayer JMA, Van Helden HPT. Weekly self-medication of leprosy patients monitored by DDS/creatinine ratios in urines. Lepr Rev, 1976, 47, 201-9.

${ }^{5}$ Jesudasan K, George B, Chacko CJG, Taylor PM, Kurian PV, Job CK. An evaluation of the self-administration of DDS in Gudiyatham Taluk. Leprosy India, 1976, 48, 668-76.

${ }^{6}$ Naik, SS, Ganapati R. Regularity of dapsone intake by leprosy patients attending urban treatment centre. Leprosy India, 1977, 49, 207-15.

${ }^{7}$ Balakrishnan S. Monitoring self administration of dapsone by patients. Leprosy India, 1977, 49, 364-71.

${ }^{8}$ Huikeshoven H, Bijleveld I. Encouraging results from DDS urine analysis among registered leprosy patients in the Wangas, Kenya. An exception that challenges the rule. Lepr Rev, 1978, 49, 47-52.

${ }^{9}$ Naik SS. Irregularity of dapsone intake in infectious leprosy patients attending an urban treatment centre. Its magnitude and causes. Lepr Rev, 1978, 50, 45-53.

10 Nigam P, Siddique MIA, Pandey NR, Awasthi KN, Sriwastava RN. Irregularity of treatment in leprosy patients. Its magnitude and causes. Leprosy India, 1979, 51, 521-32.

11 Balakrishnan S, Christian M. Assessment of self-administration of dapsone in urine by out-patients attending field clinics. Leprosy India, 1979, 51, 568-9 (abstract of conference paper). 
12 Gyi KM, Lwin MM, Myaing YY, Oo KM, Shwe T. Reliability of dapsone selfadministration by leprosy patients in the Rangoon area. Lepr Rev, 1978, 49, 283-6.

13 Hagan KJ, Smith SE, Gyi KM, Lwin MM, Myaing YY, Oo KM, Shwe T, Tin KM, Than $\mathrm{KN}$, Hla T, Kywe WW. The reliability of self-administration of dapsone by leprosy patients in Burma. Lepr Rev, 1979, 50, 201-11.

14 World Health Organization WHO Expert Committee on Leprosy Fifth Report. Bull Wld Hlth Org Techn Rep Ser No 607, 1977.

15 Engvall E, Perlmann P. Enzyme-linked immunosorbent assay, ELISA. III. Quantitation of specific antibodies by enzyme-labeled anti-immunoglobulin in antigen-coated tubes. $J$ Immunol, 1972, 109, 129-35.

${ }^{16}$ Holmgren J, Svennerholm AM. Enzyme-linked immunosorbent assays for cholera serology. Infect Immunity, 1973, 7, 759-63.

17 Huikeshoven H, Landheer JE, Van Denderen AC, Vlasman M, Leiker DL, Das PK, Goldring OL, Pondman KW. Demonstration of dapsone in urine and serum by ELISA inhibition. Lancet 1978, i, 280-1.

18 Huikeshoven H, De Wit M, Soeters A, Eggelte TA, Landheer JE, Leiker DL. ELISA inhibition technique for the demonstration of sulphones in body fluids. I. Sulphones specific antibody-enzyme conjugate. Lepr Rev 1979, 50, 275-81. 